https://helda.helsinki.fi

\title{
The problems of legitimation and potential conflicts in a world political community
}

\section{Patomäki, Heikki}

2012-06

Patomäki , H 2012 , ' The problems of legitimation and potential conflicts in a world political

pÿcommunity ' , Cooperation and Conflict, vol. 47 , no. 2 , pp. 239259 . https://doi.org/10.1177/0010836712443174

http://hdl.handle.net/10138/233394

https://doi.org/10.1177/0010836712443174

acceptedVersion

Downloaded from Helda, University of Helsinki institutional repository.

This is an electronic reprint of the original article.

This reprint may differ from the original in pagination and typographic detail.

Please cite the original version. 
This is a post-peer-review, pre-copyedit version of an article published in Cooperation and Conflict, vol. 47, issue 2. The final authenticated version is available online at: https://doi.org/10.1177/0010836712443174.

\section{The Problems of Legitimation and Potential Conflicts in a World Political Community}

\section{Heikki Patomäki}

Key words

cosmopolitanism, democracy, functionalism, identity, learning, legitimacy, normative, security, telos, temporality, world history

Social relations and practices of a world state, or any form of world political community (WPC), would require constant support, authorisation and validation in a complex and pluralistic world. For Max Weber (1978: 31) the validity of a political rule is not a normative concept, but Jürgen Habermas (1976: 97) aptly criticises Weber's empiricism. Legitimacy is not only a matter of institutionalised prejudices and behavioural dispositions, but is based also on normative validity claims - even though it is also true that a lack of good normative reasons is only a potential source of actual conflicts and crises in any political community. In this sense, all anticipations of a world state imply claims about its legitimation, i.e. possible normative reasons for the validity of its rule that could, under favourable circumstances, translate into a 'public opinion' supporting or at least accepting its rule. The concept of 'public opinion' is itself reflexively multi-layered and complex, the constitution of which would be part of the problem of legitimation in a WPC (cf. Patomäki, 1997: 165-73).

Some of the prevailing anticipations of a world state constitute fairly weak claims in terms of its legitimation. For instance, it is often maintained that a number of trends and tendencies are pointing towards planetary integration, and ultimately, a world state. The number of units has been declining. Although developments have not been linear, the overall trend is striking: from perhaps as many as 200,000-300,000 units in 1000 BCE to mere 200 units in 2000 ACE. (Carneiro 1978) A parallel trend is towards larger-sized units. Christopher Chase-Dunn et.al. (2008) identify several major upward sweeps in the recent history of humanity. Upward sweeps are defined as instances in which the largest settlements and/or polities significantly increase in size for the first time in a given area or globally. So far the peaks have been the Mongolian and British empires. Assuming that these trends continue, humanity is likely to end up in a single political unit within the next 200-300 years, but would this trend (alone) make the rule of this single political unit valid in any sense? 
Real tendencies are causal and transfactual and thus more profound than mere empirical trends. From a scientific realist perspective, Wendt (2003) argues that given the generic boundary conditions of the world system, the system is directed towards the realisation of a world state. 'The mechanism that generates this outcome is the interaction between struggles for recognition at the microlevel and cultures of anarchy at the macro' (ibid.: 507). Wendt argues that attempts to use violence in Hegelian struggles over recognition have become increasingly expensive and also dysfunctional due to the development of technology, especially weapons of mass destruction. Perhaps even more importantly, 'any social order founded on unequal recognition [is] unstable in the long run' (ibid.: 513). 'Territorial state sovereignty is by very nature a structure of unequal recognition' (ibid.: 515). Thus the logic of recognition must result in a global political community, involving a supra-national 'we'-feeling.

At the 'macro-level', the step-by-step problem-solving and learning through different 'cultures of anarchy' point to the same direction: from Hobbesian state of nature, via society of states, world society and collective security, to a world state or republic. Moreover, by taking political economy into account as well, the cosmopolitan conclusion appears even stronger. Wendt (ibid.: 494) also mentions the significance of distributional struggles, but more generally, it can be argued that the mechanisms and contradictions of global political economy create dilemmas that are not easy to overcome, not even temporarily, without adequate collective institutions (cf. Chase-Dunn 1990; Markwell 2006; Patomäki 2008), which may also constitute elements of world statehood.

Claims about material and structural tendencies towards a world state constitute reasons for normative arguments in favour of a more adequate system of global governance or, sometimes, for world government proper. Since Immanuel Kant (1983/1795), K'Ang (2005/1913) and Wells (1902; see also Wagar, 1961), the choice facing humanity has often been presented in stark terms: the likely alternative to building common global institutions to overcome the problem of organized violence is an unthinkably horrific future catastrophe - or even the end of humanity. On this basis, Kant himself argued that we have a cosmopolitan moral duty to realise a league of nations. He envisaged a cosmopolitan moral and legal order, but was opposed to a world state. Many later Kantians have thought that only a world state could truly resolve the dilemmas of organised violence that Kant so perceptibly analysed.

Also the Hegelian metaphor of 'struggle for recognition', when applied to the history of humankind as a whole as Wendt does, amounts to a cosmopolitan normative argument, which stems from the principle of equality of all humans. 
This equality can be expressed for instance in terms of political, social or civil rights, possibly implying global democracy. Likewise, political economy arguments for better global institutions are grounded on normative considerations. Political economy arguments for planetary unification profess, apart from peace, goals such as rational economic policies; distributive justice; autonomy; and democracy. The establishment of adequate global economic institutions to govern the world economy would be a step in 'the long march of mankind toward its unity and better control of its own fate' (Triffin, 1968: 179).

\section{The research problem and structure of the paper}

Every argument about the possibility, desirability and/or inevitability of a world state entails claims and assumptions about its future legitimacy and sustainability. To pose questions about the possible basis of legitimacy of a world state does not imply a commitment to any particular telos of world history. Although I agree with critical cosmopolitans that world history is in some way directed towards further planetary integration (see Patomäki, 2010; Patomäki \& Steger 2010), it does not follow that the telos of this process is known. A WPC and its organizational structures may turn out an emergent phenomenon; something that cannot be deduced from ex ante reasoning or anticipated in essential aspects and regards, but fully known, only ex post to its emergence. Hence, the category of 'state' may - or may not - be misleading in thinking about WPC and organizations, as the term 'world' refers to a whole that is evolving. An ethico-political goal for the world history as a whole can only be set from within history; must be fallible; and can only make sense in terms of particular story or scenario told within a particular time-scale. Thus conceived, the process leading to an end-state must be more important than the telos itself. ${ }^{1}$

The point of posing questions about legitimation in a future WPC is shedding light on the possible ethico-political grounds for further global integration. Among other things, the analysis of elements and dynamics of legitimation also facilitates the assessment of the feasibility of different paths towards planetaryscale integration and potential for conflicts, divisions and subsequent disintegration. What are the deep but historically evolving normative and institutional underpinnings that could make a sustainable WPC possible? What could provide legitimacy to a WPC and thus make it viable; and what are the potential and likely pitfalls of such an abstract, large-scale political community?

These questions have been posed before. For instance, Hans Morgenthau (1960: 522-4) defined a world community as a community of at least partly shared moral standards and political judgements and multiple but convergent political 
actions. He articulated the problem of legitimation in terms of three questions (ibid.: 511). (1) Are peoples willing to accept world government, or are they at least not so unwilling as to erect an insurmountable obstacle to its establishment? (2) Would they be and able to do what is necessary to keep world government standing? (3) Would they be willing and able to do or refrain from doing what world government requires of them so that it may fulfil its purposes? Morgenthau thought he can settle these questions with a few 'obvious' examples. Would the Americans be 'prepared to give a world government the powers to open up the borders of the United States for the annual immigration of, say, 100,000 Russians, 250,000 Chinese, and 200,000 Indians?' (ibid.: 513). Thus, 'so long as men continue to judge and act in accordance with national rather than supranational standards and loyalties, the world community remains a postulate that still awaits its realization' (ibid.: 524).

Morgenthau frames his questions in terms of Max Weber's (1978: 31) empiricist approach: '[S]ocial action may be guided by the belief in the existence of a legitimate order. The probability that action will actually be so governed will be called the validity of the order in question.' However, the Weberian empiricist approach overlooks the underlying, structurally conditioned dispositions and liabilities, on the one hand, and the normative aspects of the problem of legitimacy, on the other hand. It is true that claims about legitimacy or its lack must be relatable, in some way, to the actual preferences of individual people, however formed (which is one of the multilayered and complex senses of 'public opinion'). Further, those claims must be falsifiable by empirical means. It is nonetheless necessary also to explore (i) historically evolving and structurally conditioned dispositions and liabilities; (ii) processes of political will-formation; and (iii) normative aspects of claims about legitimacy in a way that makes it possible to build plausible scenarios about possible futures.

First I discuss the standard security and political economy arguments for a world state. Although these arguments are relevant and plausible, the question is whether they provide a basis for the possibility of a legitimate planetary political community? Could these arguments really constitute an ethico-political ground for a fully-fledged self-organizing world political system (i.e. democratic world government or something analogical)? As indicated also by the example of the European integration, the security-military and functionalist political economy arguments for planetary unification may work to a point, but after that they may also become irrelevant and in some contexts even counterproductive or selfdefeating. For example, a constant reminder of the potential German security threat may turn out a source of divisions rather than support further integration. 
The problem of legitimacy concern also normative questions: whether and why a given order or system deserves the allegiance of its members? Mere security or functionalist benefits, especially if perceived in terms of rationally calculative orientation of action, are not enough. There must also be a belief in normative legitimacy, which may be anchored in the universality principles such as popular democracy and human rights. However, there is an internal relationship between democracy and identity, and identities tend to be particular. Global-democratic 'self'-determination would presuppose a 'we' and 'us'. Who is this 'we'? Furthermore, what also matters are the moral standards and political judgements that constitute the multiple political actions and struggles over the definition of different 'selves' and ethico-political directions in the future WPC. I explore theories of civilizing process and stages of ethico-political learning and focus especially on their implications to the process of legitimation in a WPC.

$\underline{\text { Legitimacy and the materialist, structuralist and functionalist arguments for a }}$ world state

Every argument for a world state is also a proposal for the basis of its legitimation after its establishment. For instance, those advocating the classical security-military argument try to convince, in a Hobbesian manner, ${ }^{2}$ the rational members of their audience to submit their wills to a central authority in order to avoid risking a major military catastrophe in the future (Deudney, 2000 and 2008: ch 8; K'Ang, 2005; Morgenthau, 1960: 530-9; Wagar, 1961, 1999; Wells, 1902; Wendt, 2003: 516-28). As anticipated by Kant and later K'Ang and H.G.Wells, the system of separate states is loaded with powers of destruction characteristic of the planetary-nuclear era: jet airplanes, rockets and missiles, satellites and nuclear explosives. ${ }^{3}$ These powers may remain idle for a relatively long time, say until 2044, or 2100, or even further into the 22nd century, yet under particular - however exceptional - future circumstances they may come to be instigated, resulting in a global disaster. Similarly, one can argue that in order to overcome 'the tragedy of commons' (Hardin 1968) which may threaten our survival as a species, we need a common state. Especially when securitised in this manner, climate change and other critical biosphere-related issues can be framed as just as salient as the potential for a major military catastrophe in the future. Once a world-state is in place, every rational actor is then assumed to accept the validity of its rule out of (sheer or generalized) self-interest.

The security-military argument is conceptually ambiguous. It is ambiguous ex ante of the establishment of a world state or anything analogical, because the Hobbesian argument is meant to justify obedience to an existing state (by warning people what would happen if they did not obey), not to justify creating 
a new one. From an ex ante perspective, the security-military argument is vulnerable to the collective action problem. (See fn 2; and Wendt, 2003: 509). Ex post, or after, the establishment of a global state, this argument would all too easily serve as a constant reminder of the potential threat posed by concrete others and related stories about past wrong-doings. Moreover, the argument is conservative: it justifies any order against any claims to change. Yet, there will always be disputes and conflicts between social forces. There can never be a stable 'order', an eternally fixed set of practices and institutions. It is not possible to tame or freeze history for a long time. History is a changing and open-ended process. New interests and claims will emerge and new 'messages' demanding changes will be sent and made public.

The security-military argument may thus become counterfinal from the point of view of establishing a security community (Deutsch et.al., 1957; Lijphart, 1981; Patomäki, 2002: ch 8; Adler \& Barnett, 2008). To simplify: if, despite sustained efforts, there is no responsiveness from the side of status quo forces, a pathological learning process may occuramong the advocators of changes. Over time, this may lead to the escalation of conflict and (threats of) violence. The preparedness to use large-scale violence inside and/or outside indicates nonintegration and is a sign of an insecurity community - inside and outside. In contrast, security communities are characterised by the expectation that future changes are going to be peaceful; and that the others can be trusted in a generic manner. Regional or global integration generates non-preparedness to use violence. This can be explicated as follows:

A1. If a social system has become integrated, no relevant actor has any reasons to prepare for the use of political violence.

A2. As actors know (A1), they do not expect anybody to use political violence either to preserve status quo or to foster changes.

B1. Non-preparedness becomes a generally followed and rarely, if ever, questioned rule of action.

B2. In the course of social time, (A2) becomes an automatic, routine-like and self-evident presupposition of political thought, argumentation and action.

Thus in stage B, the security argument fades into the social background of the 'the-taken-for-granted'; and the security community becomes and asecurity community, in which security is no more an issue. The case of European integration seems to support this generic conclusion. The security-military argument is being used to legitimise the EU, and it has motivating power among some actors, but its factual role tends to be limited. Instead of just contributing 
to 'we'-feeling and collective identity, the security-military argument can also reinforce the separation of different identities and 'public opinions' and also for that reason, stage B2 may not be reached.

These problems probably explain why - despite the dramatic force of the security-military argument - functionalist political economy arguments are usually more popular. A number of contemporary issues and contradictions of global political economy require trans - and supranational co-operation and institutions, with at least some centralised direction. Practical-technical cooperations that imply de facto or de jure sharing of sovereignty and common institutions are steps towards a world state. (Weiss, 2009) Moreover, from this point of view, a world state may come to be organised along functionalist lines; it does not have to resemble existing territorial states (see e.g. Partington, 2003; Wells, 2002). The functionalist line of argumentation for a world state comes close to the Monnet-method of European integration. The economistic expectation of many functionalists such as David Mitrany is that political loyalties and, and thereby mainstream beliefs in the legitimacy of the system, should more or less automatically follow the transfer of technical, economic and welfare functions from the nation-state to international and supranational organizations. After the failure of the post-World War II federalistic projects, the Western European integration process started as a functionalistic system of cooperation loosely along the lines of the theories of Jean Monnet (as officially articulated by Schuman, 1994) and David Mitrany (1943; 1975). Despite some attempts to introduce explicitly political notions such as citizenship, this approach still characterizes the development of the EU.

However, the legitimation problems of the EU - as is evident from several unfavourable referenda to the 2010 crisis of the EMU - have also shown the limits of the Monnet-method (for a theoretical analysis, see Patomäki, 1997). Although functionalist and neo-functionalist theories are motivated by criticalreflexive moral considerations, the basic thrust of the economistic-functionalist argument seems to presuppose the fulfilment of Weber's historical scenario about the development of capitalism, in which the operations of the abstract, quantitative and most impersonal media, money, displace all action-orientations other than the rationally calculative orientation, and especially those that are based on ethico-political values or any meanings considered significant to the lives and actions of individuals and collectives (for discussions, see Weber, 1978). To the extent that (i) the instrumentalist orientation prevails in society and (ii) trans- or supranational co-operation is widely seen as more efficient than national, the functionalist argument - abstracted from a wider social context and its inbuilt normative principles - may possibly work to a certain point. 
However, these conditions can never be met more than partially. Although Weber has been right about the overall trend of the 20th century history, the displacement of other action-orientations can never be completed (see Habermas, 1981 and 1984; Connolly 1993). Moreover, there have also been counter-movements working against the tenets of Weberian modernisation (as well as against related processes of commodification in the Marxian sense). Thus attempts to push functionalist political economy integration beyond the limits of prevailing loyalties, solidarities and ethico-political sentiments are insufficient and may also become counterproductive in terms of reactions against the implied instrumentalism, utilitarism and accompanying commodification, however moral the underlying motivation may be.

Another problem with the security and functionalist arguments is that they ignore the lessons of the historical processes of modern state-formation. Modern European states could not have succeeded in progressively establishing their legitimate monopoly over violence by just dispossessing their competitors of instruments of physical violence by stronger means of violence. Neither did they prove their worth by mere technical-functionalist means. They also engaged in what Norbert Elias (1978) calls the 'civilizing process', involving the adoption of religious pluralism among states and, often, also religious freedom within the state; and embraced new universalising principles while forging particular national imaginaries to justify and legitimise their territorial rule.

\section{The 'civilizing' process and stages of ethico-political learning}

Between 1776 and 1848 there arose on both sides of the Atlantic universalistic principles of rights and justice. However, att this geo-historical moment, many in Europe were still more than willing to sacrifice their lives for the divine rights of the dynastic rulers and aristocracy and thus fight against the American and French revolutions and related universalizing principles. Moreover, production remained based on land and agriculture (the Industrial Revolution started to have transformative effects in Britain only from the 1820s onwards); and the speed of communication and transportation across the surface of the planet was limited to the velocity of humans, horses and sailing ships. Under these circumstances, universalizing principles could only be realized 'nationally'.

The collective identity of citizens developed under the abstract viewpoints of legality, morality, and sovereignty, especially through modern natural-law constructions and in formalist ethics. According to Habermas (1979: 115), 'these abstract determinations are best suited to the identity of world citizens, not to that of the citizen of a particular state. [... ]'. Under these circumstances, the 
resources of the 'nation-state' were harnessed to forge and circulate prototypes, metaphors and frames that would legitimize its rule. The new national categories also captured the imagination of historians, philosophers and poets.

Thus, nationalism became a transformative force in the modernizing world. Nationhood found its concrete political expression in the transformation of subjects into citizens who laid claim to equal membership in the nation and institutionalized their autonomy within the modern nation-state. But who really counted as part of the people and what constituted the essence of the nation became the subject of fierce intellectual debates and social struggles. The 'national imaginary' corresponds to what Anderson (1991) has called 'modern imaginings of the nation' as a spatially limited and sovereign community of individuals. Their knowledge of each other was, in most cases, not direct, but mediated in 'homogenous, empty time' through the diffusion of discursive literacy and the prototypes, categories, metaphors, and framings cultivated within it. To a large extent, the national imaginary was made possible by the invention of printing technology embedded in nascent capitalism.

To the extent that my criticism of the incompleteness and potentially counterproductive nature of the materialist, structuralist and functionalist arguments for world integration is correct, a WPC requires a global imaginary and a related 'civilizing' process. A world state or, more generally, a WPC is unlikely to emerge, or be sustainable, without a 'civilizing' and story-telling process appropriate for the identity of world citizens. A key question is: would this 'civilizing' and story-telling process resonate with deep tendencies underlying actual geo-historical events, episodes and trends? Are there reasons to believe that world history is somehow - inevitably or otherwise - taking humanity into a cosmopolitan direction; and that attempts to 'civilize' humankind further and cultivate planetary stories about the common fate of humanity are thus grounded on deep non-contingent logics or mechanisms?

Wendt (2003: 510-16) relies on Hegel's metaphorical story about the 'struggle for recognition' in arguing that only a global political community can ensure an equal, symmetric and stable collective identity and solidarity. This Hegelian story is instructive, but its epistemological and ontological status is unclear. It is based on assumptions human desire and constitution of Self that may appear plausible to some, or even perhaps to many, yet they do not seem to be grounded on claims with falsifiable implications. Thus Wendt's interpretation of Hegel's story may be indicative of the possibility of a trans-historical logic taking humanity towards a WPC, but not much more.

Andrew Linklater $(1982 ; 1990 ; 1998 ; 2007)$ has articulated an alternative - and more normatively oriented - account of the reasons for believing in the gradual 
emergence of a WPC. From the viewpoint of ethical universalism (1982), he argues that the success or failure of the critical theory of international relations will be determined by the amount of light cast on present possibilities of change towards a universal human moral community (1991: 172). Linklater's idea is that by knowing the factors contributing to the development of the moral community of humankind, or cosmopolis, it should be possible to strengthen, perhaps even in a somewhat instrumentalist manner, these alternative tendencies. For example, Linklater maintains that the capitalist world economy has generated complex interdependencies and various transnational forces that are assembling the conditions for a universal human community. (See Linklater, 1991; 1998; 2007) The overall argument is, as in the case of Wendt, indicative; there seem to be a number of normative, sociological and geo-historical reasons to expect the emergence and, then, consolidation of a WPC.

Arguably, both Linklater's project of critical theory and Wendt's Hegelian story are essentially about collective learning. Ethical universalism is a result of collective learning, although, for the time being, various geo-historical factors and social conditions and prevent it from being adopted widely enough. The Hegelian story about the dialectical movement of one moment of 'recognition' to another depicts essentially an ideal-typical human learning process. In real geo-historical time, each moment can last up to centuries, or even more.

Similarly, a 'civilizing process' is based on increasing awareness and respect for other people's point of view (Linklater, 2007: 162). In effect, the concept refers to the collective learning of humanity, but in an unspecified way.

As Jean Piaget, Lawrence Kohlberg, Habermas and other have argued, there are good and empirically confirmed reasons to think that certain kinds of cognitive structures emerge in a logical order that constitute what can be called 'stages' (seen as iconic models of generic structures, idealized and abstracted from complex and in some ways also vague and ambiguous reality). ${ }^{4}$ Stages are inner generative of cognitive processing embodied in the habitus of individuals. ${ }^{5}$ Each higher stage is able to answer questions or problems unsolved at the next lower stage. A partial analogy can be made between individual and collective learning, although there are also major ontological and normative differences between the two. In both cases the sequence of cognitive stages is conceptual-logical rather than just empirically correct. This explains why an individual can reach higher stages in a sufficiently enabling context spontaneously and why the order of learning must be roughly the same in both cases. The generative structures of reasoning can become to be embedded in social practices and institutions, although this is always contingent on many things, including political struggles. 
Collective human learning sheds light for instance on the quest for democratization. Rules are not anymore taken as something external to individual actors and thus sacred or conventional in the authoritative sense; but rather come to be felt as the free product of mutual agreement and an autonomous conscience. In other words, actors come to understand that collective rules are the product of their autonomy and free, mutual agreement (Piaget, 1977: 24-5; Kohlberg, 1971: 164-5). Collective learning also points towards cosmopolitan moral sentiments. At the critical-reflexive level of reasoning, morality and general ethico-political principles must have validity and application apart from (i) the authority of the groups or persons holding these principles; and (ii) apart from the individuals own identification with any particular groups or institutions. Critical-reflexive ethico-political orientation is thus fully apt only for world citizens.

Normative validity is of course different from the actual course of history. Collective learning occurs via political debates and struggles that can take the form of: consensus or compromise agreements; dialogues and debates; majoritydecisions; manipulation of the background context; outright force; or a combination of these. Typically asymmetric relations of structural power favour quite systematically a particular outcome. Moreover, history is open-ended: even if an end-point should have been achieved, the future must remain open. In this critical-reflexive sense, there is nothing final about any particular historical telos such as global democracy realized within the framework of a world political community of some sort. Thus understood, global democracy is not the only purpose or the ultimate end-point of human history; but it provides a normatively compelling direction to the world history in the 21 st century.

The problem of collective identity: who are 'we'?

Collective learning anticipates a telos of world history in which all others are recognised and constituted as fully autonomous subjects with a legitimate social standing in relation to the Self. This telos can only be realized within the framework of common planetary institutions. However, global solidarity and common institutions would raise a new problem. Can there be any solidarity without a common identity at some level of human beingness? Is a shared global political identity possible only if it implies different outsiders, understood largely in negative evaluative terms, perhaps antagonistically as enemies?

Would a global identity thus require outsiders to the humankind as a whole? Arash Abizadeh (2005) explains how many of the standard arguments, according to which collective identity presupposes human others, are fallacious. 
Followers of Hegel tend to commit the fallacy of composition. Even though individual self-consciousness may require recognition by others, and although the identity of individuals may be dialogically constructed, it does not follow that collective identities are constructed in the same way. Collectively, nothing else is required than the mutual recognition of, and dialogues among, the individuals and groups who form that collective identity. It is admittedly true that international legal sovereignty (which is a collective identity) presupposes recognition by another sovereign (another collective identity), but international legal sovereignty is a contingent geo-historical institution, not a metaphysical or trans-historical truth. Furthermore, the followers of Carl Schmitt infer the actuality and effectivity of collective physical violence from its abstract possibility and thus in effect define politics in terms of war. The Schmittians thus reify a contingent outcome as an eternal truth about the nature of politics.

However, I concur with the post-structuralists that in human language and reasoning negativity and thus some 'othering' is inevitable. Thus it is essential to go beyond demonstrating negatively the possibility of a global identity; we should also ask 'possible yes, but exactly how?'. If some othering is inevitable, what are the possible structures of a global identity-construction? When the aim is to avoid repressive, antagonistic and potentially violent self-other relations, there are basically three options. Firstly, otherness can be placed outside the human species and planet Earth. The cosmic viewpoint provides an important source - even a foundation - for global identity although this is not a sufficient solution to the problem of identity (see Patomäki, 2010). For instance, calls for global solidarity in the face of rapid global warming (e.g. UNDP, 2007) assume a shared planetary identity across the currently prevailing differences and divisions. Environmentalists correctly maintain that all humans share an important thing in common: planet Earth and its sphere of life to which we humans essentially belong. Our cultural differences are built on a shared cosmic and biological basis. Thus a possible argument for universal morality and thereby for world identity involves an idea that we should work together as a species to preserve and cultivate life and the human potential on a planetary scale, and even beyond, on a cosmic scale.

Secondly, otherness can be located either in our own past or, alternatively, in our contemporary being, when seen from a point of view of a possible future position in world history. As any process of identity-construction is temporal, this constitutes a fruitful perspective, but does not address all the key problems or tackle the onto-logical underpinnings of the standard identity-theories. There is thus, thirdly, a need to rethink the basic onto-logic of identity from a perspective that is compatible with an emerging framework called Big History (e.g. Christian, 2005; Patomäki \& Steger, 2010). Utilizing the concept of a 
horizon of moral identification and developing further Todorov's axis of selfother relations, it is possible to outline a cosmic, temporal, and relational conception of global identity based on both positive and negative elements.

\section{$\underline{\text { Temporalising identities and Geo-Historical Narratives }}$}

Any identity is always temporal, not only in the simple sense of being located in time (and space), but because ethico-political identity discloses itself as sameness over time that can only be established in and through narratives that the actors are telling (cf. Ricoeur, 1992: chps 5-6). Modern collective identities are constituted through geo-historical stories of actions and characters. It is the identity of the story that makes the identity of the actor and character (ibid.: 148). From a emporal perspective, although othering may in some sense be inevitable, the most relevant identity-constituting others need not be those contemporary humans on the planet Earth who are in some regards - ethically, culturally or otherwise - different from us, whoever we are.

Otherness can also be located either in our own past or, alternatively, in our contemporary being, when seen from a point of view of a possible future position in world history. In other words, what we are can be defined, through stories, in terms of critical distance from what we once used to be. And what we may become and would like to become can be defined in terms of critical distance from what we are now, in terms of stories involving possible and likely future developments. Critical distance from one's own past entails the possibility of normative improvement and ethico-political learning and development. A key to a successfulovercoming of violent antagonisms seems to lie in collective learning via mutual self-criticism. If one looks deep enough, the history of every group, every class and every country is filled with episodes that not only could but also should have been otherwise. In that sense it is always possible to locate layers of negative otherness in one's own collective past - and from a universalizing perspective, we know that this applies to everyone on the planet. At this level of universalization, critical distance from one's own identity and from the prevailing ideas and practices of one's own society does not mean inverting established hierarchies or oppositions, but rethinking the hierarchies and oppositions in terms of higher-order identities.

A potentially even more important possibility is locating otherness in our contemporary being and identity, when seen from a point of view of a possible future position in world history. As Wendt argues in terms of the 'struggle for recognition' story: 
[...A] world state could compensate for the absence of spatial differentiation between its present and its past [...]. The past here is anarchy, with all its unpleasantness. In Hegelian terms we could say that 'history' becomes the Other in terms of which the global self is defined. Of course this Other does not have a subjectivity of its own, and so cannot literally recognize the world state. But a functional equivalent to recognition can be achieved by an act of temporal self-differentiation. (Wendt, 2003: 527)

For Wendt the temporal self-differentiation would occur in the future when the world state is established. However, the idea of temporal self-differentiation and otherness can be made concrete already now by imagining for instance a future historian or sociologist looking back. This device has been successfully utilized in some science fiction writings (e.g. Brunner, 1971; Wagar, 1999). The act of imagining a future historian generates far-reaching questions about his or her identity, about our identity, and about the truth of his or her historical stories and explanations. Arguably, our future historian is likely to identify with the planetary political community as a whole, possible extending his or her moral horizon even way beyond Earth, and looking at the human past from this kind of a global vantage point. A leap ahead into the future seems thus to suggest a standpoint of some sort of planetary history. This general standpoint does not stop interpretation of history from being contested. As in any political community, history will be periodically re-interpreted and constantly debated also in a future WPC. ${ }^{6}$ But in contrast to more limited histories, world history covers the planetary history of humanity in its entirety.

Karl Jaspers (1953) was one of those who articulated the increasingly common sentiment that the world is now a single unit of communications. This, he assumed, gives rise to a growing drive toward political unification, maybe through mutual agreement in a world order based on the rule of law. For Jaspers, this constitutes the beginning of the world history proper. It is 'the spiritual and technical acquisition of the equipment necessary for the journey; we are just setting out' (ibid.: 24). This setting out also entails a new planetary understanding of the human past. In fact, H.G.Wells worked on the idea of a universal history already in the aftermath of the First World War. In his twovolume Outline of History, Wells argued for the importance of shared historical ideas. "Swifter means of communication have brought all men closer to one another for good or for evil" and thus "war becomes a universal disaster". However, there can be no common peace and prosperity without common historical ideas; a sense of history as the common adventure of all mankind is necessary for peace. (Wells, 1920: v-vi) 
There had been universal histories - presentations of the history of mankind as a whole, as a coherent unit - before Wells, but most of them have told the story in Eurocentric terms, often assuming or suggesting that a particular (Christian or) Western society constitutes the end-point of world history. In contrast, Wells framed the world history cosmic and biological terms and imagined a future world society, indeed a world state, thus providing an entirely new, futureoriented vantage point. Following Wells, a succession of $20^{\text {th }}$ century writers, particularly since the rise of environmentalist concern, and the opening of outer space, have sought to generate geo-historical narratives of the human past, present and future to serve as an ideational unity of a united humanity. The late 1980s saw a systematic and globalist critique of Eurocentrism rising. The colonizers' model of the world - Eurocentrism - is based on a simple and yet false assumption: all important concepts, practices, technologies and capacities have emerged from Europe or from Europeanized parts of the world.) The critics of Eurocentrism have argued plausibly that this is a biased and one-sided account of the common adventure of all mankind (Amin, 1989; Blaut, 1993; Blaut, 2000; Frank, 1998; Hobson, 2004; Needham, 2004; Pomeranz, 2000). The starting point of the non-centric and neo-Wellsian Big History is that human societies remain part of cosmos and nature, "properly at home in the universe despite our extraordinary powers, unique self-consciousness, and inexhaustible capacity for collective learning' (McNeill 2005: xvii).

McNeill argues further that as natural sciences have been historicized at many levels, it is now the task of historians - and social scientists - to generalize boldly enough to connect their area of study with the history of the cosmos, solar system and life. In this genre, David Christian's (2005) Maps of Time. An Introduction to Big History is a unified story of developments of the whole universe from the Big Bang about 13 thousand million years ago through the present into its distant future (see also e.g. Brown, 2007). The story of Big History is about the emergence of new layers of qualitatively distinct beings and development of increasing complexity locally - against the background of the second law of thermodynamics that tends to work against complexity in the cosmos as a whole (see also Kauffman, 1995; and Wheeler, 2006). From this perspective, we can see that life on Earth emerged from cosmic evolution (although we do not yet know all the details as of how) and humanity from biological evolution (this part is better known). This amounts to a modern creation myth with a cosmopolitan intent, told in scientific terms (for a discussion on the more Nietzschean and regressive variations of the evolutionary themes, see Patomäki, 2010: 16-7).

The so called modern time has been the most dramatic era in the common adventure of all humankind thus far. The Eurocentric waves of globalization - 
starting with the imperial reintegration of the American continent with Europe and continuing with the late 19th century and early 20th century waves of neoimperial expansion - have intensified the new global coming together of humanity, even if characteristically under violent, oppressive and tragic circumstances. The Industrial Revolution led to a rapid global population growth from one to nearly seven billion people today; this growth continues at least until the benchmark of nine billion will be reached probably in the early 2040s. Simultaneously, the Industrial Revolution also complicated and obscured the connection between available resources and control over land.

From a Eurocentric perspective, the 19th century appeared exceptional. The core of the industrializing world economy seemed to have become relatively peaceful, although its outward expansion was violent. Hence, despite recurring wars in the colonies, the rise of neo-imperialism from the 1870s onwards, and subsequent armament race, the First World War came as an immense surprise to most Europeans. Thereby, the 20th century, 'the age of extremes' (Hobsbawm, 1994), began with a largely unanticipated catastrophe, recurring on a truly global scale in 1937-1945. Moreover, the Russian revolution is unlikely to have occurred without the war (and German support for the Bolshevists). Thus, also the Cold War was a co-product of the First World War and its aftermath. It was at this time that humanity reached the technological capacity to destroy itself and large parts of the ecological systems of the planet; and it was at that time that world history proper emerged for the first time.

In a rather Wellsian manner, Big History is necessarily oriented also towards the future. Among other things, it presupposes the possibility of collective learning and anticipates possibilities such as global security community and much better governance of common global processes and problems. These kinds of anticipations amount to the process of unification of humanity at least in some form, although Christian (2005), like so many others, remains agnostic about the possibility of a world state. Big History frames world history in planetary and cosmic terms and imagines a future WPC that may also assume the form of a world state, thus providing a new vantage point for writing history and viewing ourselves. From that perspective, what we are now - whoever we may be in terms of our identity - constitutes a form of possibly negative otherness.

$\underline{\text { Redefining the three axis of self-other relations }}$

Big History may provide a rough framework for thinking about who the 'we' are, but it cannot - and ought not try to - abolish historical and cultural differences within humanity. Moreover, togetherness not only creates new 
points of contact but may also engender new points of conflict. In view of the legitimacy potential for a WPC, there is thus a need to rethink the basic ontologic of identity from a perspective that is simultaneously compatible with (i) the post-structuralist and other critics of false universalisms and (ii) the possibility of collective learning and Big History. Ontologically, as the world is differentiated, structured and layered, and since it is the condition of being in general that there are absences, level-specific voids, differences, contrasts etc, there must always be certain differences, contrasts and exclusions also within humanity. Among other things, these differences translate into contestations over the validity and substance of narratives about human history as a whole.

Usefully, Tzvetan Todorov's (1984) has distinguished among three axes of ego/alter-relations. The first is the epistemological axis. Ego can either know or be ignorant of alter's history, identity and values. Knowledge or ignorance of the other can also have deep epistemological roots. From many standpoints, differences are difficult to see. Answers to the question 'how can and should we acquire knowledge?' enable and constrain visions and knowledge of the others. Of course, there can be no absolute knowledge but an endless gradation of the lower or higher states of knowledge, including in self-knowledge. Nonetheless, in the contemporary world, the viewpoint of Big History means better knowledge of the others. It also gives grounds for refashioning systems of education along non-centric lines of the global imaginary. At least in the epistemic and epistemological axis, Big History implies improvement in selfother relations, as it levels out the roles and contributions of different parts of humanity to its common history - that may only be starting.

The axiological axis, the basis for value judgments, is partly independent of knowledge. Better knowledge does not necessarily imply more favourable judgments (cf. ibid.: 185). Empirical descriptions can be unfavourable in relation to cultural background assumptions or prevailing moral reasoning, and especially a judgment on the ontological status of others. Thus, it is critical whether the other is judged to be an equal or a 'lower' being. Modern progressive time - and the idea of stages of development - has often defined the status of self as advanced and others as inferior in terms of standards of an imperial cultural formation. Also Big History allows for learning and advancement in human history. Is it necessary that claims to collective learning must justify colonialism or imperialism, however tacitly?

Even if it was true that social and cultural developments of humans have gone through rather similar - but non-synchronic - structural phases in different parts of the planet, it can be argued that temporal advances in terms of ethico-political learning do not justify ethico-political hierarchies, violence or repression. With a 
sufficiently wide horizon of moral identification, it can be acknowledged that the socio-cultural development of the others may have been slower and to some extent different because of contingent, structural and path-dependent reasons. If anything, the parallels and advances have been surprisingly similar. Moreover, learning involves also forgetting. Other cultural formations include characteristics that 'we' may have either forgotten or had never developed, i.e. mutual learning is always possible. Moreover, belongings and rights can be universally valid also when the others do not reason in a universalistic manner. Why should temporally 'backward' others be deprived of their entitlements when they do not articulate their claims in the same way as we do (cf. Muthu 2003: 172-209)?

Todorov's third axis, the praxiological axis, has to do with rapprochement with or distancing from other's real or imagined identity and values in practical terms. Neutrality or indifference is a possibility and this implies the capacity to take critical distance metaphorically and sometimes also literally. Todorov (1984: 185) argues that in the absence of distance-taking there are only two possibilities: either the ego embraces the other's identity and values and identifies; or the ego identifies the other with himself. These options imply either submission to the other or the other's submission to oneself.

Todorov fails to give ethico-political room to the idea that their identities can be co-constitutive but not exhausted by their mutual relations; and to the possibility that interaction between ego and alter may over time transform both.

Nevertheless, later in the book Todorov writes (ibid.: 249), albeit somewhat hesitantly, that 'we want equality without its compelling us to accept identity; but also difference without its degenerating into superiority/inferiority'. This opens up further positive possibilities but nonetheless ignores temporality and the idea of being as becoming. Any particular human ego and alter are moments in the common adventure and cultural evolution of all humankind. Thus the category of a co-constitutive and mutually transformative relationship between ego and alter should be included in the possibilities, and its centrality for the shared identity stressed. Within a higher level identity-in-difference, a coconstitutive and mutually transformative relationship between self and its others can involve letting many differences just be. What is more, the process may lead to unexpected learning processes and outcomes. 'We' may become something different from what we now expect, hope and fear.

The terms of these kinds of debates are very different in the 21st century context of global communications than they were in the early 16th century Spain, when it was natural for parties to appeal to the Bible in making their case for or against the Indians - and no Indian was asked to participate in the debates. In the 
$21^{\text {st }}$ century conversations, the audience is much wider, often truly global, and anyone can claim access to the process. This necessitates trans-cultural and ecumenical arguments across many divisions (cf. Alker, 1996: ch 4).

\section{$\underline{\text { Conclusions }}$}

In this paper, I have argued that while the standard security-military and functionalist political economy arguments for planetary unification and political community may work to a certain point, they are incomplete and may also, or tend to, become counterproductive. What ultimately matter are the moral standards and political judgements that constitute multiple political actions and struggles in a future WPC. Moreover, this is not merely an empirical, Weberian problem. The problem of legitimacy is also normative: whether and why a given order or system deserves the allegiance of its members?

Mere security or functionalist benefits, especially if perceived in terms of rationally calculative orientation of action, are not enough. There must also be a belief in normative legitimacy, which may be anchored in universal principles such as popular democracy and human rights. In this light, I have explored theories of civilizing process and stages of ethico-political learning. Collective human learning not only explains the quest for democratization but also points towards cosmopolitan moral sentiments. However, there is an internal relationship between democracy and identity, and identities tend to be particular. Global-democratic 'self'-determination presupposes a 'we' and 'us'. Who is this 'we'? I have made a case, first, for thinking that otherness can be located in our own past or, alternatively, in our contemporary being, when seen from a point of view of a possible future position in world history. Second, within a higher level identity-in-difference, a co-constitutive and mutually transformative relation between self and others can involve letting many differences just be.

Cosmopolitan, planetary identity implies the acknowledgement of irreducible differences within humanity itself, however unstable and changing they may be. Moreover, these differences can also be seen as drivers of further human learning - also concerning our place in the wider cosmic scheme of things.

\section{$\underline{\text { References }}$}

Angell, N (2000) The Great Illusion. 1933 ed. North Stratford, N.H : Ayer Company Publishers (orig. published 1909). 
Abizadeh, A (2005) Does Collective Identity Presuppose an Other? On the Alleged Incoherence of Global Solidarity. American Political Science Review (99)1: 45-60.

Adler, E \& Barnett, M (ed.) (1998) Security Communities. Cambridge: Cambridge University Press.

Amin, S (1989) Eurocentrism. New York: Monthly Review Press.

Blaut, J.M. (1993) The Colonizer's Model of the World. Geographical Diffusionism and Eurocentric History. New York: The Guilford Press.

Blaut, J.M. (2000) EightEurocentric Historians. New York: The Guilford Press.

Boom, J, Wouters, H and M Keller (2007) A Cross-Cultural Validation of Stage Development: A Rasch Re-Analysis of Longitudinal Socio-Moral Reasoning Data. Cognitive Development (22):2 213-29.

Brown, CS (2007) Big History. From the Big Bang to the Present. New York: The New Press.

Carneiro, R (1978) Political Expansion as an Expression of the Principle of Competitive Exclusion. In R. Cohen and E. Service (eds) Origins of the State. Philadelphia: Institute for the Study of Human Issues, pp.205-23.

Chase-Dunn, C (1990) World State Formation: Historical Processes and Emergent Necessity. Political Geography Quarterly (9)2: 108-30.

Chase-Dunn, C, Alexis A, O Chan, B Fierro and H Inoue (2008) Upsweep Inventory: Scale Shifts of Settlements and Polities in World-Systems Since the Stone Age. A paper presented at the annual meeting of the International Studies Association, March 26, 2008, San Francisco, Session WB37 Theory and History in World-Systems Research.

Connolly, WE (1993) Political Theory \& Modernity. Ithaca: Cornell University Press.

Christian, D (2005) Maps of Time. An Introduction to Big History. Berkeley, CA: University of California Press. 
Dawson, TL (2002) New Tools, New Insights: Kohlberg's Moral Judgement Stages Revisited. International Journal of Behavioural Development, (26):2 $154-66$.

Deudney, D (2000) Geopolitics as Theory: Historical Security Materialism. European Journal of International Relations, (6)1: 77-107.

Deudney, D (2008) Bounding Power: Republican Security Theory from the Polis to the Global Village. Republican Security Theory from the Polis to the Global Village. Princeton NJ: Princeton University Press.

Deutsch, KW. et al. (1957) Political Community and the North Atlantic Area. International Organization in the Light of Historical Experience. Princeton, NJ: Princeton University Press.

Elias, N (1978) The Civilizing Process. The History of Manners. Trans. by E.Jephcott, New York: Urizen Books (orig. published in 1939).

Frank, AG (1998) ReORIENT: Global Economy in the Asian Age. Berkeley, CA: University of California Press.

Gibbs, JC., Basinger, KS., Grime, RL and JR Snarey (2007) Moral Judgment Development Across Cultures: Revisiting Kohlberg's Universality Claims. Developmental Review (27):4 443-500.

Habermas, J (1976) Legitimation Crisis. Trans T. McCarthy, London: Heinemann.

Habermas, J (1979) Communication and the Evolution of Society. Trans T. McCarthy, Boston: Beacon Press.

Habermas, J (1990a) Justice and Solidarity: On the Discussions Concerning 'Stage 6'. In M.Kelly (ed.): Hermeneutics and Critical Theory in Ethics and Politics. Cambridge, MA: The MIT Press, pp.32-52.

Habermas, J (1990b) Moral Consciousness and Communicative Action. Trans. by C.Lenhardt and S.Weber Nicholsen. Cambridge, MA: The MIT Press.

Hardin, G (1968) The Tragedy of the Commons. Science 162(3859): 1243-1248.

Hobsbawm, EJ (1994) Age of Extremes: The Short Twentieth Century 19141991. London: Abacus. 
Hobson, JM. (2004) The Eastern Origins of Western Civilisation. Cambridge: Cambridge University Press.

Jaspers, K (1953) The Origin and Goal of History. Trans. by M. Bullock. London: Routledge \& Kegal. Paul.

K'Ang Yu-Wei (2005) Ta T'Ung Shu (The One-World Book). Trans. L.G.Thompson. London: Routledge (english transl. 1958, first partial orig. publication 1913).

Kant, I (1983) Perpetual Peace and Other Essays. Trans. T. Humphrey. Indianapolis, IN: Hackett (the main essay orig. published in 1795).

Kohlberg, L (1971) From Is to Ought: How to Commit the Naturalistic Fallacy and Get Away with It in the Study of Moral Development. In T.Mischel (ed.): Cognitive Development and Epistemology. New York: Academic Press, pp.151235.

Kohlberg, L (1973) The Claim to Moral Adequacy of a Highest Stage of Moral Judgment. Journal of Philosophy, 70(18): 630-46.

Kohlberg, L (1981) The Philosophy of Moral Development. Moral Stages and the Idea of Justice. Essays on Moral Development Volume 1. San Francisco: Harper \& Row.

Krebs, DL \& Denton, K. (2006) Explanatory Limitations of CognitiveDevelopmental Approaches to Morality. Psychological Review, (113)3: 672-75.

Las Casas, B de la. 1992[1542]. A Short Account of the Destruction of the Indies. Trans. by N. Griffin. London: Penguin.

Latour, B (2004) Whose Cosmos, Which Cosmopolitics?, Common Knowledge (10)3: 450-62.

Lijphart, A (1981) Karl W. Deutsch and the New Paradigm in International Relations. In R. Merritt and B. Russett (eds) From National Development to Global Community. Essays in Honour of Karl.W.Deutsch. Boston: Allen and Unwin, pp.233-251.

Linklater, A (1982) Men and Citizens in the Theory of International Relations. London: Macmillan Press. 
Linklater, A (1990) Beyond Realism and Marxism. Critical Theory and International Relations. Hampshire \& London: Macmillan.

Linklater, A (1998) The Transformation of Political Community: Ethical Foundations of a Post-Westphalenian Era. Cambridge: Polity Press.

Linklater, A (2007) Critical Theory and World Politics. Citizenship, Sovereignty and Humanity. London: Routledge.

Lizardo, O (2004) The Cognitive Origins of Bourdieu's Habitus. Journal for the Theory of Social Behaviour, (34)4: 375-401.

Markwell, D (2006) John Maynard Keynes and International Relations. Economic Paths to Peace. Oxford: Oxford University Press.

McNeill, WH (2005) Foreword. In Maps of Time. An Introduction to Big History, Christian, David. Berkeley, CA: University of California Press.

Mitrany, D (1943) A Working Peace System. An Argumentfor the Functional Development of International Organization. London: Royal Institute of International Affairs/Oxford: Oxford University Press.

Morgenthau, H (1960) Politics among Nations. The Strugglefor Power and Peace, 3rd edition. New York: Alfred A, Knopf.

Muthu, S (2003) Enlightenment Against Empire. Princeton and Oxford: Princeton University Press.

Neal, P (1989) Hobbes and Rational Choice Theory. Western Political Quarterly (41)4: 635-52.

Needham, J (2004) Science and Civilisation in China, Vol.7, Part 2: General Conclusions and Reflections, ed. K.Robinson. Cambridge: Cambridge University Press.

Partington, JS (2003) Building Cosmopolis. The Political Thought of H.G. Wells. Aldershot: Ashgate, 2003.

Patomäki, H (1997) EMU and the Legitimation Problems of the European Union. In P.Minkkinen \& H.Patomäki (eds.): The Politics of the European Monetary Union, Dordrecht: Kluwer, pp.164-206. 
Patomäki, H (2002) After International Relations. Critical Realism and the (Re)Construction of World Politics. London: Routledge.

Patomäki, H (2008) The Political Economy of Global Security. War, Futures Crises and Changes in Global Governance. London: Routledge.

Patomäki, H (2010) Cosmological Sources of Critical Cosmopolitanism'. Review of International Studies, (37)S1: 181-200.

Patomäki, H (forthcoming). On the Stages of Ethico-Political Learning. A manuscript in progress.

Patomäki, H \& Steger, MS (2010) Social Imaginaries and Big History: Towards a New Planetary Consciousness? Futures (41)10: 1056-1063.

Pomeranz, K (2000) The Great Divergence. China, Europe and the Making of the Modern World Economy. Princeton, NJ: Princeton University Press.

Piaget, J (1977) The Moral Judgement of the Child. Transl. by M.Gabain. Harmondsworth, Middlesex: Penguin (orig. published in 1932).

Piaget, J (2002) The Language and Thought of the Child. Transl. by M. and R.Gabain. London: Routledge (orig. published in 1923).

Ricoeur, P (1992) Oneself as Another. Transl. by K. Blamey. Chicago: The University of Chicago Press.

Schuman, R (1994) The Schuman Declaration. In B.F.Nelsen and A-C.G.Stubb (eds.) The European Union. Readings in the Theory and Practice of the European Union. Boulder, CO: Lynne Rienner (orig. published in 1950).

Sonnert, G (1994) Limits of Morality: A Sociological Approach to Higher Moral Stages. Journal of Adult Development, (1)2: 127-34.

Todorov, T (1984) The Conquest of America: The Question of the Other. Trans. by R. Howard. New York: Harper \& Row.

Triffin, R (1968) Our International Monetary System: Yesterday, Today, and Tomorrow. New York: Random House. 
UNDP (2007) Human Development Report 2007/2008. Fighting Climate Change: Human Solidarity in a Divided World. New York: UNDP/Palgrave MacMillan.

Wagar, WW (1961) H.G.Wells and the World State. New Haven: Yale University Press.

Wagar WW (2004) H.G.Wells. Traversing Time. Middletown, CT: Wesleyan University Press.

Wagar, WW (1999) A Short History of the Future. Chicago: The University of Chicago Press.

Weber, M (1978) Economy and Society, Volume One, edited by G.Roth \& C.Wittich. Berkeley: University of California Press.

Weiss, TG (2009) What Happened to the Idea of World Government?, International Studies Quarterly (53)2: 253-271.

Wells, HG. (1902) Anticipations of the Reaction of Mechanical and Scientific Progress upon Human Life and Thought. London: Chapman \& Hall, Ld.; freely available from http://www.gutenberg.org/etext/19229 (accessed 19 May 2010).

Wells, HG (1920) The Outline of History. Being a Plain History of Life and Mankind. London: The Waverley Book Co.

Wells HG (2002) The Open Conspiracy. In W.Wagar, ed., The Open Conspiracy. H.G.Wells on World Revolution, Westport, CT: Praeger, orig. published in 1933).

Wendt, A (2003) Why a World State is Inevitable. European Journal of International Relations (9)4: 491-542.

\section{Endnotes}

\footnotetext{
${ }^{1}$ Even more fundamentally, every telos is necessarily temporary and transitional in some scale of time. There are no ultimate ends in the world of multiple simultaneously on-going processes.

${ }^{2}$ Hobbes' Leviathan can be read as a rhetorical - but also onto-theological - argument that tried to convince readers to submit their wills to the sovereign authority of the absolute monarch. Unless they do this, they risk, under the conditions of a modern society, the peace of their society with devastating consequences. The 'state of
} 
the nature' was thus an imagined future possibility, meant to be a 'shock therapy' for those who doubted the validity of the rule of the Monarch. The argument was targeted ag ainst the Cromwellian reformers of Britain, who were, in Hobbes'opinion, causing civil war(s) and political violence. See e.g. Neal, 1988; Connolly, 1993, 16-40; and Hobbes' (1974: 101) about the historical non-existence of the 'state of nature'.

${ }^{3}$ Wells foresaw an aerial war before the innovation of aeroplanes. Furthermore, in 1913, Wells forecasted the development of the atomic bomb and nuclear power, and imagined a hugely destructive worldwide atomic war to be fought later in the 20th century: 'it is chaos or the United States of the World for mankind; there is no other choice'; this second-hand quote is from Wagar (2004: 141), published originally from the preface of a 1917 reissue of Wells' The War in the Air.

${ }^{4}$ I am referring to well-known works such as Piaget (1977, 2002), Kohlberg (1971, 1973, 1981) and Habermas (1979, 1990a, 1990b). For discussions on the empirical validity of the Kohlbergian framework in particular, see e.g. Boom, Wouters and Keller, 2007; Dawson, 2002; Gibbs, Basinger, Grime and, 2007; Krebs and Denton 2006; and Sonnert, 1994. In Patomäki (forthcoming), I discuss the criticism according to which any attempt to posit a particular discursive or cultural formation, or institutional framework, as 'progressive' implies (metaphorical or literal) violence and a new unjustified social hierarchy. This criticism can be read reconstructively as an important corrective and addendum to critical-reflexive ethico-political reasoning. Moreover, I also explore possible further stages of ethico-political learning: history has no end.

5 The Bourdieun concept of habitus has its origins in Piaget's genetic structuralism and theories of learning; Lizardo, 2004. The habitus of embodied actors is a generative dynamic structure that adopts and accommodates itself to a field composed primarily of otherembodied actors and geo-historically situated practices and institutions within which actors are positioned. A habitus is made possible and constituted by the collective historical development of schemata of perception, prototypes, categories, metaphors and framings, and of explicit ideas and theories built upon these foundations.

6 To this extent I agree with Bruno Latour (2004) who criticizes objectivist cosmopolitanism and argues for explicit cosmopolitics. For Latour, cosmopolitics recognizes the radical pluralism of understandings and the fact 'that the parliament in which a common world could be assembled has got to be constructed from the scratch' (ibid., 462). This goes a bit too far, however, and ignores both the shared geo-historical background of the gradually evolving human capabilities and the recently emerged global industrial civilization. The contemporary industrial civilization is more global and comprehensive than anything that has occurred before. (See Braudel, 1995: 8-14) We have multiple histories and cultures in the context of a single scientific-technological and politico-economic global civilization that includes a number of international, regional and global institutions (for a discussion on the proposals for a practical world parliament from this perspective, see Patomäki 2007).

Although Latour thus overstates his case, I concur that all attempts to narratize world or global histories are, and will be in the foreseeable future, mediated by the pre-existing multiple cultures. 